\title{
Synthesis and Screening of Some Novel 2-[5-(Substituted phenyl)- $[1,3,4]$ oxadiazol-2-yl]-benzoxazoles as Potential Antimicrobial Agents
}

\author{
Hemalatha Gadegoni*, Sarangapani Manda ${ }^{\dagger}$, and Shivaprasad Rangu* \\ Jayamukhi College of Pharmacy, Narsampet, Warangal-506332, (AP), India \\ *E-mail: hemagadegoni@yahoo.co.in \\ †niversity College of Pharmaceutical Sciences, Kakatiya University, Warangal-506009, (AP), India \\ Department of Chemistry, Kakatiya University, Warangal-506009, (AP), India.
}

(Received September 23, 2012; Accepted January 22, 2013)

\begin{abstract}
A series of some novel 2-[5-(substituted phenyl)-[1,3,4]oxadiazol-2-yl]-benzoxazoles were synthesized by using benzoxazole-2-carboxylic acid on reaction with thionyl chloride in presence of ethanol solvent at room temperature gave benzoxazole-2-carbonyl chloride, which is turned into benzoxazole-2-carboxylic acid hydrazide on reaction with hydrazine hydrate in ethanol solvent under reflux. The subsequent treatment of benzoxazole-2-carboxylic acid hydrazide with an appropriate aromatic carboxylic acid in presence of polyphosparic acid under reflux afforded the title compounds. The chemical structures of the newly synthesized compounds were elucidated by their IR, ${ }^{1} \mathrm{H}$ NMR and Mass spectral data analysis. Further the compounds are used to find out their ability towards anti microbial and nematicidal activity.
\end{abstract}

Key words: 1,3,4-Oxadiazole, Benzoxazole, Antimicrobial activity, Antifungal activity, Nematicidal activity

\section{INTRODUCTION}

The main objective of the medicinal chemistry is to synthesize the compounds that show promising activity as therapeutic agents with lower toxicity. During recent years there have been some interesting developments in the biological activities of benzoxazole derivatives. Benzoxazoles have special significance in the field of medicinal chemistry due to their remarkable pharmacological potentialities. Benzoxazoles have received considerable attention in diverse areas of chemistry. ${ }^{1,2}$ The small and simple benzoxazole nucleus is present in compounds involved in research aimed at evaluating new products that possess interesting biological activities such as antiviral, ${ }^{3}$ antimi-

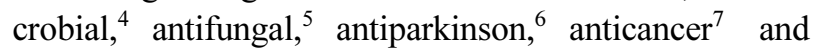
antibiotic ${ }^{8}$ properties. They are also used as ligands for asymmetric transformations. ${ }^{9}$ A number of methods have been reported for the synthesis of these heterocycles which include condensation of carboxylic acids ${ }^{10}$ and their derivatives like orthoesters, ${ }^{11-13}$ nitriles, ${ }^{14}$ amides, ${ }^{15}$ aldehydes ${ }^{16}$ and esters ${ }^{17}$ with o-substituted aminoaromatics. Beckmann rearrangement of o-acylphenol oximes ${ }^{18}$ and photocyclization of phenolic Schiff bases also produce these compounds. ${ }^{19}$ Synthetic routes that are common to the preparation of these heterocycles typically involve the reaction of a carboxylic acid or its derivatives with an appropriate 1,2-phenylenediamine, 2-aminophenol or 2-aminothio phenol in the presence of a strong acid at elevated temperatures. ${ }^{20,21}$

The oxadiazole chemistry has been developed extensively and is still developing. Presently there are a number of drugs used clinically, which comprise oxadiazole moiety in association with various heterocyclic rings. 1, 3, 4-oxadiazoles are biologically active, synthetically useful and important heterocyclic compounds. The synthesis of novel oxadiazole derivatives and investigation of their chemical and biological behavior have gained more importance in recent decades for biological, medicinal and agricultural reasons. Different classes of oxadiazole compounds possess an extensive spectrum of pharmacological activities. Differently substituted oxadiazole moiety has also been found to have other important activities such as antibacterial, ${ }^{22}$ antimalarial, ${ }^{23}$ anti-inflammatory, ${ }^{24}$ antifungal, ${ }^{25}$ anticonvulsant, ${ }^{26}$ analgesic, ${ }^{27}$ antimicrobial, ${ }^{28}$ antimycobacterial, ${ }^{29}$ anticonvulsant, ${ }^{30}$ antitumor, ${ }^{31}$ antimalarial, ${ }^{32}$ herbicidal, ${ }^{33}$ vasodialatory, ${ }^{34}$ cytotoxic,${ }^{35}$ hypolipidemic, ${ }^{36}$ ulcerogenic ${ }^{37}$ and antiedema. ${ }^{38}$ The biological significance of these compounds impelled us to continue the work on the synthesis of some new and novel heterocycles.

\section{EXPERIMENTAL}

All reagents and solvents were used as purchased without further purification. Melting points were determined on a Fisher-Johns melting point apparatus and are uncor- 
rected. Crude products were purified by column chromatography on silica gel of $60-120$ mesh. IR spectra were obtained on a PerkinElmer BX serried FTIR 5000 spectrometer using $\mathrm{KBr}$ pellet. NMR spectra were recorded on a Varian $300 \mathrm{MHz}$ spectrometer for ${ }^{1} \mathrm{H}$ NMR. The chemical shifts were reported as ppm down field using TMS as an internal standard. Mass spectra were recorded on a VG-Micromass $7070 \mathrm{H}$ spectrometer operating at $70 \mathrm{eV}$.

\section{General procedures for synthesis of benzoxazole-2- carbonyl chloride 2}

To a solution of benzoxazole-2-carboxylic acid $\mathbf{1}(0.01$ $\mathrm{mol})$ in ethanol $(20 \mathrm{ml})$, thinly chloride $(0.01 \mathrm{~mol})$ was added. The mixture was stirred at room temperature for $3 \mathrm{~h}$. After completion of the reaction (monitored by TLC, EtOAc: petroleum-ether, 2:1) then the mixture was poured in water $(30 \mathrm{ml})$ and extracted with $\mathrm{Et}_{2} \mathrm{O}(3 \times 20 \mathrm{ml})$. The organic phase was separated, and dried over $\mathrm{Na}_{2} \mathrm{SO}_{4}$. Evaporation of the solvent gave benzoxazole-2-carbonyl chloride 2 in $69 \%$ yields as brown solid; m.p.: $125-127^{\circ} \mathrm{C}$; IR $\left(\mathrm{KBr}, \mathrm{cm}^{-1}\right) v_{\max }: 3035,1775,1635,1579,1552,1498$, 1147; ${ }^{1} \mathrm{H}$ NMR (300 MHz, $\left.\mathrm{CDCl}_{3}\right) \delta: 7.46(\mathrm{~d}, 1 \mathrm{H}, \mathrm{J}=8.0$ Hz, Ar-H), 7.83 (dd, 1H, J = 7.5, 1.5 Hz, Ar-H), 7.98 (d, $1 \mathrm{H}, \mathrm{J}=8.5 \mathrm{~Hz}, \mathrm{Ar}-\mathrm{H}), 8.12$ (dd, $1 \mathrm{H}, \mathrm{J}=7.5,1.5 \mathrm{~Hz}, \mathrm{Ar}-\mathrm{H})$; MS, m/z (\%) $181\left(\mathrm{M}^{+}\right)$.

Synthesis of benzoxazole-2-carboxylic acid hydrazide 3

To a mixture of benzoxazole-2-carbonyl chloride $2(0.01$ $\mathrm{mol}$ ) in $10 \mathrm{ml}$ of absolute ethanol and hydrazine hydrate $(0.04 \mathrm{~mol})$, was added. Then the reaction mixture was refluxed for $8 \mathrm{~h}$. After completion of the reaction (monitored by TLC), it was then diluted with ice-cold water ( 20 $\mathrm{ml}$ ) and the solid obtained was purified by crystallization from ethanol to afford pure product benzoxazole-2-carboxylic acid hydrazide 3 in $72 \%$ yields as pale yellow solid; m.p.: $136-138^{\circ} \mathrm{C}$; IR $\left(\mathrm{KBr}, \mathrm{cm}^{-1}\right) v_{\max }: 3038,1780$, 1640, 1582, 1565, 1152; ${ }^{1} \mathrm{H}$ NMR (300 MHz, DMSO-d 6 )

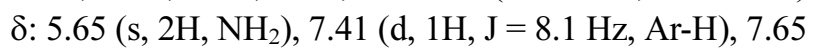
(dd, 1H, J = 7.8, 1.1 Hz, Ar-H), 7.71 (s, 1H, CONH), 7.89 $(\mathrm{d}, 1 \mathrm{H}, \mathrm{J}=8.7 \mathrm{~Hz}, \mathrm{Ar}-\mathrm{H}), 8.05$ (dd, $1 \mathrm{H}, \mathrm{J}=7.8,1.1 \mathrm{~Hz}, \mathrm{Ar}-$ $\mathrm{H}) ; \mathrm{MS}, \mathrm{m} / \mathrm{z}(\%) 177\left(\mathrm{M}^{+}\right)$.

Synthesis of 2-[5-(substituted phenyl)-[1,3,4]oxadiazol-2-yl]-benzoxazoles 4 a-g

A mixture of benzoxazole-2-carboxylic acid hydrazide $3(0.01 \mathrm{~mol})$ and substituted benzoic acid $(0.01 \mathrm{~mol})$ was heated at $100-120^{\circ} \mathrm{C}$ in presence of excess polyphosphoric acid (PPA) for 4-5 h. After cooling, the mixture was poured into crushed ice, and neutralized with $5 \%$ aq. $\mathrm{NaHCO}_{3}$ solution. The precipitated solid was filtered and purified using column chromatography (petroleum ether: ethyl acetate, 9:1).

\section{2-(5-Phenyl-[1,3,4]oxadiazol-2-yl) benzoxazole 4a}

Yellow solid; Yield : $75 \%$, m.p.: $154-156^{\circ} \mathrm{C}$; IR (KBr, $\left.\mathrm{cm}^{-1}\right) v_{\max }: 3040,1795,1652,1565,1545,1135 ;{ }^{1} \mathrm{H}$ NMR $\left(300 \mathrm{MHz}, \mathrm{CDCl}_{3}\right) \delta: 7.42-7.25(\mathrm{~m}, 5 \mathrm{H}, \mathrm{Ar}-\mathrm{H}), 7.53(\mathrm{~d}$, $1 \mathrm{H}, \mathrm{J}=7.8 \mathrm{~Hz}, \mathrm{Ar}-\mathrm{H}), 7.80$ (dd, 1H, J = 7.7, $1.5 \mathrm{~Hz}, \mathrm{Ar}-\mathrm{H})$, 7.89 (d, $1 \mathrm{H}, \mathrm{J}=8.0 \mathrm{~Hz}, \mathrm{Ar}-\mathrm{H}), 8.45$ (dd, $1 \mathrm{H}, \mathrm{J}=7.7,1.5$ $\mathrm{Hz}, \mathrm{Ar}-\mathrm{H}) ; \mathrm{MS}, \mathrm{m} / \mathrm{z}(\%) 263\left(\mathrm{M}^{+}\right)$.

\section{2-[5-(2-Chloro-phenyl)-[1,3,4]oxadiazol-2-yl]-benzox- azole 4b}

Brown solid; Yield : $78 \%$, m.p.: $174-176^{\circ} \mathrm{C}$; IR (KBr, $\left.\mathrm{cm}^{-1}\right) v_{\max }: 3045,1785,1648,1584,1565,1155 ;{ }^{1} \mathrm{H}$ NMR $\left(300 \mathrm{MHz}, \mathrm{CDCl}_{3}\right)$ 8: 7.54-7.05 (m, 4H, Ar-H), 7.66 (d, $1 \mathrm{H}, \mathrm{J}=8.0 \mathrm{~Hz}, \mathrm{Ar}-\mathrm{H}), 7.75$ (dd, $1 \mathrm{H}, \mathrm{J}=7.7,1.8 \mathrm{~Hz}, \mathrm{Ar}-\mathrm{H})$, 7.85 (d, $1 \mathrm{H}, \mathrm{J}=8.2 \mathrm{~Hz}, \mathrm{Ar}-\mathrm{H}), 8.12$ (dd, $1 \mathrm{H}, \mathrm{J}=7.7,1.8$ $\mathrm{Hz}, \mathrm{Ar}-\mathrm{H}) ; \mathrm{MS}, \mathrm{m} / \mathrm{z}(\%) 297\left(\mathrm{M}^{+}\right)$.

\section{2-[5-(2-Bromo-phenyl)-[1,3,4]oxadiazol-2-yl]-benzox- azole $4 c$ \\ Pale yellow solid; Yield : $74 \%$, m.p.: $145-147^{\circ} \mathrm{C}$; IR $\left(\mathrm{KBr}, \mathrm{cm}^{-1}\right) v_{\max }: 3025,1790,1632,1570,1555,1152 ;{ }^{1} \mathrm{H}$ NMR (300 MHz, DMSO-d 6 ) 8: 7.50-7.06 (m, 4H, Ar-H), $7.52(\mathrm{~d}, 1 \mathrm{H}, \mathrm{J}=7.9 \mathrm{~Hz}, \mathrm{Ar}-\mathrm{H}), 7.84$ (dd, $1 \mathrm{H}, \mathrm{J}=8.1,1.7$ $\mathrm{Hz}, \mathrm{Ar}-\mathrm{H}), 8.12$ (d, 1H, J = 8.5 Hz, Ar-H), $8.65(\mathrm{dd}, 1 \mathrm{H}, \mathrm{J}$ $=8.1,1.7 \mathrm{~Hz}, \mathrm{Ar}-\mathrm{H}) ; \mathrm{MS}, \mathrm{m} / \mathrm{z}(\%) 342\left(\mathrm{M}^{+}\right)$.}

\section{2-[5-(2-Methyl-phenyl)-[1,3,4]oxadiazol-2-yl]-benzox- azole 4d \\ Yellow solid; Yield : $75 \%$, m.p.: $165-167^{\circ} \mathrm{C}$; IR (KBr, $\left.\mathrm{cm}^{-1}\right) v_{\max }: 3020,1802,1630,1585,1565,1152 ;{ }^{1} \mathrm{H} \mathrm{NMR}$ (300 MHz, $\left.\mathrm{CDCl}_{3}\right) \delta: 2.40\left(\mathrm{~s}, 3 \mathrm{H}, \mathrm{CH}_{3}\right), 7.54-7.06(\mathrm{~m}$, 4H, Ar-H), 7.62 (d, 1H, J = 8.8 Hz, Ar-H), 7.95 (dd, 1H, J $=7.5,1.5 \mathrm{~Hz}, \mathrm{Ar}-\mathrm{H}), 8.21$ (d, 1H, J = 8.2 Hz, Ar-H), 8.45 $(\mathrm{dd}, 1 \mathrm{H}, \mathrm{J}=7.5,1.5 \mathrm{~Hz}, \mathrm{Ar}-\mathrm{H}) ; \mathrm{MS}, \mathrm{m} / \mathrm{z}(\%) 277\left(\mathrm{M}^{+}\right)$.}

\section{2-[5-(4-Chloro-phenyl)-[1,3,4]oxadiazol-2-yl]-benzox- azole $4 \mathrm{e}$ \\ Brown solid; Yield : $70 \%$, m.p.: $144-146^{\circ} \mathrm{C}$; IR (KBr, $\left.\mathrm{cm}^{-1}\right) v_{\max }: 3015,1795,1652,1619,1582,1135 ;{ }^{1} \mathrm{H}$ NMR $\left(300 \mathrm{MHz}, \mathrm{CDCl}_{3}\right) \delta: 7.42(\mathrm{~d}, 1 \mathrm{H}, \mathrm{J}=7.8 \mathrm{~Hz}, \mathrm{Ar}-\mathrm{H}), 7.65$ $(\mathrm{d}, 2 \mathrm{H}, \mathrm{J}=7.4 \mathrm{~Hz}, \mathrm{Ar}-\mathrm{H}), 7.78$ (dd, $1 \mathrm{H}, \mathrm{J}=7.3,1.7 \mathrm{~Hz}, \mathrm{Ar}-$ H), $7.84(\mathrm{~d}, 2 \mathrm{H}, \mathrm{J}=7.4 \mathrm{~Hz}, \operatorname{Ar}-\mathrm{H}), 8.21(\mathrm{~d}, 1 \mathrm{H}, \mathrm{J}=8.2 \mathrm{~Hz}$, Ar-H), 8.32 (dd, 1H, J = 7.3, 1.7 Hz, Ar-H); MS, m/z (\%) $297\left(\mathrm{M}^{+}\right)$.}




\section{2-[5-(4-Bromo-phenyl)-[1,3,4]oxadiazol-2-yl]-benzox- azole $4 \mathrm{f}$}

Yellow solid; Yield : $77 \%$, m.p.: $136-138^{\circ} \mathrm{C}$; IR $(\mathrm{KBr}$, $\left.\mathrm{cm}^{-1}\right) v_{\max }: 3020,1785,1632,1608,1585,1145 ;{ }^{1} \mathrm{H} \mathrm{NMR}$ $\left(300 \mathrm{MHz}, \mathrm{CDCl}_{3}\right) \delta: 7.36(\mathrm{~d}, 1 \mathrm{H}, \mathrm{J}=7.8 \mathrm{~Hz}, \mathrm{Ar}-\mathrm{H}), 7.65$ $(\mathrm{d}, 2 \mathrm{H}, \mathrm{J}=7.0 \mathrm{~Hz}, \mathrm{Ar}-\mathrm{H}), 7.74(\mathrm{~d}, 2 \mathrm{H}, \mathrm{J}=7.0 \mathrm{~Hz}, \mathrm{Ar}-\mathrm{H})$, 7.81 (dd, 1H, J = 8.0, 1.5 Hz, Ar-H), 8.05 (d, 1H, J = 8.1 $\mathrm{Hz}, \mathrm{Ar}-\mathrm{H}), 8.43$ (dd, 1H, J = 8.0, $1.5 \mathrm{~Hz}, \mathrm{Ar}-\mathrm{H}) ; \mathrm{MS}, \mathrm{m} / \mathrm{z}$ (\%) $342\left(\mathrm{M}^{+}\right)$.

\section{2-[5-(4-Methyl-phenyl)-[1,3,4] oxadiazol-2-yl]-benzox- azole $4 \mathrm{~g}$}

Pale yellow solid; Yield : $75 \%$, m.p.: $158-160{ }^{\circ} \mathrm{C}$; IR $\left(\mathrm{KBr}, \mathrm{cm}^{-1}\right) v_{\max }: 3025,1805,1625,1595,1575,1155 ;{ }^{1} \mathrm{H}$ NMR (300 MHz, $\left.\mathrm{CDCl}_{3}\right) \delta: 2.80\left(\mathrm{~s}, 3 \mathrm{H}, \mathrm{CH}_{3}\right), 7.52$ (d, $1 \mathrm{H}, \mathrm{J}=7.8 \mathrm{~Hz}, \mathrm{Ar}-\mathrm{H}), 7.54$ (d, 2H, J = 7.8 Hz, Ar-H), 7.65 $(\mathrm{dd}, 1 \mathrm{H}, \mathrm{J}=7.7,1.4 \mathrm{~Hz}, \mathrm{Ar}-\mathrm{H}), 7.74(\mathrm{~d}, 2 \mathrm{H}, \mathrm{J}=7.8 \mathrm{~Hz}$, Ar$\mathrm{H}), 7.85(\mathrm{~d}, 1 \mathrm{H}, \mathrm{J}=8.2 \mathrm{~Hz}, \operatorname{Ar}-\mathrm{H}), 8.42(\mathrm{dd}, 1 \mathrm{H}, \mathrm{J}=7.7$, $1.4 \mathrm{~Hz}, \mathrm{Ar}-\mathrm{H}) ; \mathrm{MS}, \mathrm{m} / \mathrm{z}(\%) 311\left(\mathrm{M}^{+}\right)$.

\section{RESULTS AND DISCUSSION}

Inspired by the biological profile of benzoxazole and oxadiazoles and their increasing importance in pharmaceutical and biological fields, and in continuation of our research on biologically active heterocycles considering the scope to introduce 1,3,4-oxadiazole moiety into the benzooxazole, it is thought worthwhile to undertake the synthesis of the title compounds with the view to obtain certain new chemical entities with both active pharmacophores in a single molecular frame work for the intensified biological activities.

Accordingly, in this manuscript we describe the synthesis of the 2-[5-(substituted phenyl)-[1,3,4]oxadiazol-2yl]-benzoxazoles $4 \mathbf{a}-\mathbf{g}$. The syntheses of the compound 4 commenced from commercially available benzoxazole-2carboxylic acid $\mathbf{1}$. The benzoxazole-2-carbonyl chloride 2 , the key intermediate, has been prepared in $69 \%$ yield by stirring of a mixture of benzoxazole-2-carboxylic acid $\mathbf{1}$ and thionyl chloride in presence of ethanol solvent at room temperature for $3 \mathrm{~h}$ as in Scheme 1. Formation of the compound $\mathbf{2}$ was confirmed by its spectral analysis. The IR spectrum of $\mathbf{2}$ showed the absorption band corresponding to the $\mathrm{C}=\mathrm{O}$ and $\mathrm{C}=\mathrm{N}$ groups at 1775 and $1635 \mathrm{~cm}^{-1}$ respectively. The remaining absorption bands appeared at $1579,1552(\mathrm{C}=\mathrm{C}$, aromatic $), 1147(\mathrm{C}-\mathrm{O}) \mathrm{cm}^{-1}$. The proton NMR spectrum of compound 2 showed a signal at $\delta$ $8.12 \mathrm{ppm}$, as a double doublet integrating for one proton is assigned for aromatic protons and the remaining aromatic

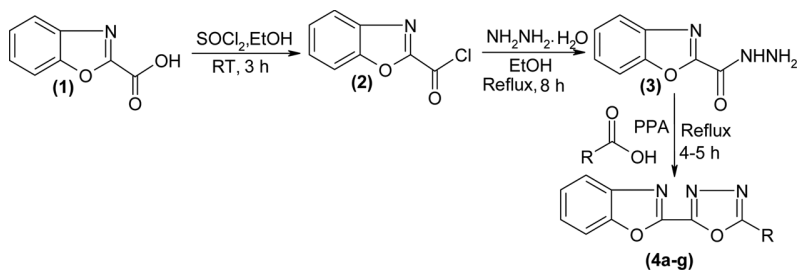

Scheme 1. $\mathrm{Ra}=\mathrm{C}_{6} \mathrm{H}_{5}, \mathrm{~b}=2-\mathrm{ClC}_{6} \mathrm{H}_{4}, \mathrm{c}=2-\mathrm{BrC}_{6} \mathrm{H}_{4}, \mathrm{~d}=2$ $\mathrm{CH}_{3} \mathrm{C}_{6} \mathrm{H}_{4}, \mathrm{e}=4-\mathrm{ClC}_{6} \mathrm{H}_{4}, \mathrm{f}=4-\mathrm{BrC}_{6} \mathrm{H}_{4}, \mathrm{~g}=4-\mathrm{CH}_{3} \mathrm{C}_{6} \mathrm{H}_{4}$.

signals at $\delta 7.98 \mathrm{ppm}$ for one proton, at $\delta 7.83 \mathrm{ppm}$ for proton and at $\delta 7.46 \mathrm{ppm}$ for proton appeared as doublet, double doublet and doublet respectively. The mass spectrum of compound showed molecular ion peak at m/z 181 .

The benzoxazole-2-carboxylic acid hydrazide $\mathbf{3}$, intermediate for the synthesis of title compounds, has been prepared by the dehydrohalogenation of benzoxazole-2carbonyl chloride $\mathbf{2}$ with hydrazine hydrate in the presence of ethanol solvent at reflux for $8 \mathrm{~h}$ to yield compound $\mathbf{3}$ in $72 \%$. Formation of the compound $\mathbf{3}$ was confirmed by its spectral analysis. In the IR spectrum of $\mathbf{3}$ the absorption band appeared at 1780 and $1640 \mathrm{~cm}^{-1}$ which are characteristic of $\mathrm{C}=\mathrm{O}$ and $\mathrm{C}=\mathrm{N}$ stretching vibrations respectively. The remaining absorption bands appeared at 1582, 1565 $\left(\mathrm{C}=\mathrm{C}\right.$, aromatic), $1152(\mathrm{C}-\mathrm{O}) \mathrm{cm}^{-1}$. The proton NMR spectrum of the compound 3 showed signals at $\delta 8.05 \mathrm{ppm}$ for one proton and at $\delta 7.65$ for one proton, both as double doublet integrating the aromatic protons. The remaining two aromatic protons appeared at $\mathrm{d} 7.89 \mathrm{ppm}$ as doublet for one proton and at $\delta 7.41 \mathrm{ppm}$ also as doublet for proton. At d $7.71 \mathrm{ppm}$ as a singlet, integrating for one proton is assigned to the $\mathrm{CONH}$ group. Another singlet signals at $\delta 5.65 \mathrm{ppm}$, integrating for one proton is assigned to the $\mathrm{NH}_{2}$ group. The mass spectrum of the compound $\mathbf{3}$ showed molecular ion peak at $\mathrm{m} / \mathrm{z} 177$.

The compound benzoxazole-2-carboxylic acid hydrazide $\mathbf{3}$, when reacted with different aromatic carboxylic acids in the presence of polyphsphoric acid (PPA) at reflux temperature for 4-5 $\mathrm{h}$ afforded the title compounds, 2-[5-(substituted phenyl)-[1,3,4]oxadiazol-2-yl]-benzoxazoles $4 \mathbf{a}-\mathbf{g}$ in $70-78 \%$ yields. Formation of the compound 2-(5-Phenyl-[1,3,4] oxadiazol-2-yl)benzoxazole 4a was confirmed by its spectral analysis. In the IR spectra of compounds $4 \mathbf{a}$ absorption bands corresponding to the $\mathrm{C}=\mathrm{O}$ and $\mathrm{C}=\mathrm{N}$ appeared at 1795 and $1652 \mathrm{~cm}^{-1}$ respectively. The absorption band signal for $\mathrm{C}-\mathrm{O}$ group appeared at $1135 \mathrm{~cm}^{-1} .{ }^{1} \mathrm{H}$ NMR spectrum of compound $\mathbf{4 a}$ showed two resonance signals at $\delta 8.45 \mathrm{ppm}$ and at $\delta 7.80 \mathrm{ppm}$ as double doublets for two protons corresponding to aromatic protons. 
Another two aromatic protons of benzoxazole ring gave two signals at $\delta 7.89 \mathrm{ppm}$ and at $\delta 7.53 \mathrm{ppm}$ as doublets with $\mathrm{J}$ value $8.0 \mathrm{~Hz}$ and $7.8 \mathrm{~Hz}$ respectively. The aromatic protons of phenyl ring appeared between $\delta 7.42-7.25 \mathrm{ppm}$ as multiplet, integrating for five protons. Mass spectrum of compound 108a showed a peak at $\mathrm{m} / \mathrm{z} 263\left(\mathrm{M}^{+}\right)$, confirming the structure of compound 4a. In summery all the chemical structures of all the newly synthesized compounds were confirmed by their IR, ${ }^{1} \mathrm{H}$ NMR, Mass and further the compounds were screened for their antibacterial, antifungal and anti-inflammatory activity.

\section{ANTIBACTERIAL ACTIVITY}

The in vitro antibacterial activity of the newly prepared 2-[5-(substituted phenyl)-[1,3,4]oxadiazol-2-yl]-benzoxazoles $\mathbf{4 a}-\mathbf{g}$ was screened against four human pathogenic bacteria viz., Escherichia coli, Klebseilla pneumoniae, Shigella dysentriae and Shigella flexnei. The zone of inhibition in $\mathrm{mm}$ at concentration $100 \mu \mathrm{g} / \mathrm{mL}$ was determined using the cup-plate method. ${ }^{39,40}$ Standard antibacterial agents such as Streptomycin and Neomycin were also screened under similar conditions for comparison and the results are presented in Table 1. The antibacterial screening data of the compounds 2-[5-(substituted phenyl)-[1,3,4]oxadiazol-2-yl]-benzoxazoles $\mathbf{4 a}-\mathbf{g}$ showed that the compounds $\mathbf{4 b}, \mathbf{4 c}, \mathbf{4 d}, \mathbf{4 e}$ and $\mathbf{4 f}$ were highly active against the entire organism employed. Compound $\mathbf{4 c}$ is highly active against all the test organisms employed and the zone of inhibition is more than the standard drug Neomycin, and almost equal to the standard drug Streptomycin. The other compounds showed moderate to good activity against these organisms employed. All the compounds displayed significant activity against $E$. coli (Table 1).

Table 1. Antibacterial activity of 2-[5-(Substituted phenyl)-[1,3,4] oxadiazol-2-yl]-benzoxazoles (4a-g) (Zone of Inhibition in $\mathrm{mm}$ at $100 \mu \mathrm{g} / \mathrm{mL})$

\begin{tabular}{lcccc}
\hline S. NO & E. coli & K. pneumoniae & S. dysentriae & S. flexnei \\
\hline $\mathbf{4 a}$ & 21 & 17 & 17 & 19 \\
$\mathbf{4 b}$ & 22 & 21 & 20 & 25 \\
$\mathbf{4 c}$ & 27 & 26 & 27 & 26 \\
$\mathbf{4 d}$ & 23 & 19 & 24 & 19 \\
$\mathbf{4 e}$ & 19 & 20 & 21 & 21 \\
$\mathbf{4 f}$ & 20 & 21 & 22 & 23 \\
$\mathbf{4 g}$ & 14 & 17 & 18 & 11 \\
Streptomycin & 30 & 30 & 30 & 30 \\
Neomycin & 20 & 20 & 20 & 20
\end{tabular}

Note: $<16 \mathrm{~mm}$, inactive; $17-20 \mathrm{~mm}$, moderately active; $20-27$ $\mathrm{mm}$, highly active.
Table 2. Antifungal activity of 2-[5-(Substituted phenyl)-[1,3,4] oxadiazol-2-yl]-benzoxazoles (4a-g) (Zone of Inhibition in $\mathrm{mm}$ at $500 \mu \mathrm{g} / \mathrm{mL})$

\begin{tabular}{lcccc}
\hline S. NO & A. niger & C. albicans & A. flavus & R. oryzae \\
\hline $\mathbf{4 a}$ & 18 & 17 & 18 & 14 \\
$\mathbf{4 b}$ & 18 & 17 & 19 & 16 \\
$\mathbf{4 c}$ & 24 & 20 & 21 & 26 \\
$\mathbf{4 d}$ & 25 & 27 & 23 & 19 \\
$\mathbf{4 e}$ & 22 & 16 & 15 & 19 \\
$\mathbf{4 f}$ & 24 & 24 & 22 & 20 \\
$\mathbf{4 g}$ & 16 & 12 & 14 & 17 \\
Griseofulvin & 18 & 17 & 18 & 14
\end{tabular}

Note: $<16 \mathrm{~mm}$, inactive; $17-20 \mathrm{~mm}$, moderately active; $20-27$ $\mathrm{mm}$, highly active.

\section{ANTIFUNGAL ACTIVITY}

The compounds 2-[5-(substituted phenyl)-[1,3,4]oxadiazol-2-yl]-benzoxazoles $\mathbf{4 a}-\mathbf{g}$ were also screened for their antifungal activity against Aspergillus niger, Candida albicans, Aspergillus flavus and Rhizopus oryzae at concentration of $500 \mu \mathrm{g} / \mathrm{mL}$ using cup-plate method. ${ }^{41}$ The antifungal activity of the compounds was compared with the standard drug Griseofulvin. The zones of inhibition formed were measured in $\mathrm{mm}$ and are given in Table 2. The antifungal screening data of the compounds $\mathbf{4 a -} \mathbf{a}$ showed that, the compounds 4d (2-methyl phenyl moiety) and $\mathbf{4 f}$ (4bromo phenyl moiety) are showing significant activity. Compound $\mathbf{4 d}$ is highly active against $A$. niger, $C$. albicans and A. flavus. The other compounds showed moderate to good activity against these organisms (Table 2).

\section{NEMATICIDAL ACTIVITY}

All the newly synthesized compounds $\mathbf{4 a - g}$ in this study was assayed for their nematicidal activity against Ditylenchus myceliophagus and Caenorhabditis elegans by aqueous in vitro screening technique, ${ }^{42}$ at various concentrations. For the nematicidal assay the $D$. myceliophagus was extracted from the cultivated mushrooms (Agaricus bisporus) infected with the nematode. The $C$. elegans was grown on $10 \mathrm{~cm}$ $8 \mathrm{P}$ plates on a $E$. coli NA22 bacteria diet, which grow in a very thick layer and constitute an abundant food source for large quantities on nematode. The nematode water suspension was collected in petri dishes. Suspension of adult worms from five day old culture was diluted with approximately 100 to 250 nematodes $/ \mathrm{mL}$ of water, $100 \mu \mathrm{L}$ of the nematode suspension was introduced into a solution of each test compound at various concentrations in a well of 
Table 3. Median lethal Dose (LD50, ppm) of 2-[5-(Substituted phenyl)-[1,3,4]oxadiazol-2-yl]-benzoxazoles (4a-g)

\begin{tabular}{ccccccccc}
\hline S. NO & $\mathbf{4 a}$ & $\mathbf{4 b}$ & $\mathbf{4 c}$ & $\mathbf{4 d}$ & $\mathbf{4 e}$ & $\mathbf{4 f}$ & $\mathbf{4 g}$ & Levamisole \\
\hline$D m$ & 790 & 850 & 560 & 600 & 170 & 430 & 570 & 170 \\
$C e$ & 760 & 770 & 360 & 550 & 190 & 220 & 870 & 180 \\
\hline
\end{tabular}

Dm $=$ D. myceliophagus; $C e=$ C. elegans

24-well plates and incubated at $25^{\circ} \mathrm{C}$. The results have been expressed in terms of $\mathrm{LD}_{50}$ i.e. median lethal dose at which $50 \%$ nematodes became immobile (dead), and compared with the standard drug Levamisole.

The screened data reveal that, $\mathbf{4 e}$ is the most effective against $D$. myceliophagus and $C$. elegans with $\mathrm{LD}_{50}$ of 170 and 190 ppm, respectively. The compounds $\mathbf{4 f}$ and $\mathbf{4 g}$ are also most active against $C$. elegans with $\mathrm{LD}_{50}$ of 200 ppm and $D$. myceliophagus with $\mathrm{LD}_{50}$ of 190 ppm, respectively. The activity of $4 \mathbf{e}$ is almost equal to the activity of the standard Levamisole. The other tested compounds showed moderate activity (Table 3 ).

\section{CONCLUSION}

In conclusion, a series of novel 2-[5-(substituted phenyl)-[1,3,4]oxadiazol-2-yl]-benzoxazoles $\mathbf{4 a -} \mathbf{g}$ have been designed and synthesized. The antimicrobial and nematicidal activity of these compounds was evaluated against various bacteria, fungi and nematodes. Among the synthesized compounds, almost all compounds showed good activity against bacteria, fungi and nematodes and emerged as potential molecules for further development.

Acknowledgments. The publication cost of this paper was supported by the Korean Chemical Society.

\section{REFERENCES}

1. Denny, W. A.; Rewcastle, G. W.; Baguley, B. J. Med. Chem. 1990, 33, 814.

2. Kondo, J.; Suzuki, N.; Imaoka, T.; Kawasaki, T.; Nakanishi, A.; Kawahara, Y. Anal. Sci. 1994, 10, 17.

3. Song, X.; Vig, B. S.; Lorenzi, P. L.; Drach, J. C.; Townsend, L. B.; Amidon, G. L. J. Med. Chem. 2005, 48, 1274.

4. Yildiz-Oren, I.; Yalcin, I.; Aki-Sener, E.; Carturk, N. Eur. J. Med. Chem. 2004, 39, 291.

5. Yamato, M. J. Pharm. Soc. Jpn. 1992, 112, 81.

6. Benazzouz, A.; Boraud, T.; Dubedat, P.; Boireau, A.; Stutzmann, J. M.; Gross, C. Eur. J.Tharmacol. 1995, 284, 299.

7. Kumar, D.; Jacob, M. R.; Reynolds, M. B.; Kerwin, S. M. Bioorg. Med. Chem. 2002, 10, 3997.

8. Evans, D. A.; Sacks, C. E.; Kleschick, W. A.; Taber, T. R. J. Am. Chem. Soc. 1979, 101, 6789.
9. Figge, A.; Altenbach, H. J.; Brauer, D. J.; Tielmann, P. Tetrahedron: Asymmetry 2002, 13, 137.

10. So, Y. H.; Heeschen, J. P. J. Org. Chem. 1997, 62, 3552.

11. Villemin, D.; Hammadi, M.; Martin, B. Synth. Commun. 1996, 26, 2895.

12. Doise, M.; Dennin, F.; Blondeau, D.; Sliwa, H. Tetrahedron Lett. 1990, 31, 1155.

13. Jenkins, G. L.; Knevel, A. M.; Davis, C. S. J. Org. Chem. 1961, 26, 274.

14. Hein, D. W.; Alheim, R. J.; Leavitt, J. J. Am. Chem. Soc. 1957, 79, 427.

15. Terashima, M.; Ishii, M. Synthesis 1982, 484.

16. Salehi, P.; Dabiri, M.; Zolfigol, M. A.; Otokesh, S.; Baghbanzadeh, M. Tetrahedron Lett. 2006, 47, 2557.

17. Chakraborti, A. K.; Rudrawar, S.; Kaur, G.; Sharma, L. Synlett. 2004, 1533.

18. Bhawal, B. M.; Mayabhate, S. P.; Likhite, A. P.; Deshmukh, A. R. Synth. Commun. 1995, 25, 3315.

19. Chen, Y.; Zeng, D. X. J. Org. Chem. 2004, 69, 5037.

20. Preston, P. N. The Chemistry of Heterocyclic Compounds; Wiley: New York, 1981; p 5.

21. Terashima, M.; Ishii, M. Synthesis 1982, 1484.

22. Andotra, C. S.; Manhas, B. S. Acta Cienc. Indica Chem. 1992, $18,99$.

23. Hutt, M. P.; Elstager, E. F.; Werbet, L. M. J. Heterocycl. Chem. 1970, 7, 511.

24. Silvestrini, B.; Pagatti, C. Br. J. Pharmacol. 1961, 16, 209.

25. Sharma, R. S.; Bahel, C. S. J. Indian Chem. Soc. 1982, 59, 877.

26. Omar, A.; Mohsen, M. E.; Aboul Wafa, O. M. J. Heterocycl. Chem. 1984, 21, 1415.

27. Narayana, B.; Vijayaraj, K. K.; Ashalatha, B. V.; Kumari, N. S. Arch. Pharm. 2008, 338.

28. Gaonkar, S. L.; Rai, K. M. Eur. J. Med. Chem. 2006, 41, 841.

29. Ali, M. A.; Yar, M. S. Bioorg. Med. Chem. Lett. 2007, 17, 3314.

30. Zarghi, A.; Tabatabai, S. A.; Faizi, M.; Ahadian, A.; Navabi, P.; Zanganeh, V.; Shafiee, A. Bioorg. Med. Chem. Lett. 2005, 15, 1863.

31. Bezerra, N. M. M.; De-Oliveira, S. P.; Srivastava, R. M.; Silva, D. Farmaco 2005, 60, 955.

32. Zareef, M.; Iqbal, R.; De Dominguez, N. G.; Rodrigues, J.; Zaidi, J. H.; Arfan, M.; Supuran, C. T. J. Enzyme Inhib. Med. Chem. 2007, 22, 301.

33. Ram, V. J.; Pandey, H. N. Eur. J. Med. Chem. 1990, 25, 541.

34. Shirote, P. J.; Bhatia, M. S. Arab. J. Chem. 2010, 145. 
35. Padmavathi, V.; Reddy, G. S.; Padmaja, A.; Kondaiah, P.; Shazia, A. Eur. J. Med. Chem. 2009, 44, 2106.

36. Jayashankar, B.; Rai, K. M. L.; Baskaran, N.; Shazia, H. S. S. Eur. J. Med. Chem. 2009, 44, 3898.

37. Shashikan, D.; Bhandari, V.; Bothara, K. G.; Raut, M. K.; Patil, A. A.; Sarkate, A. P.; Mokale, V. J. Bioorg. Med. Chem. Lett. 2008, 16, 1822.

38. Omar, F. A.; Mahfouz, N. M.; Rahman, M. A. Eur. J. Med. Chem. 1996, 31, 819.
39. Seely, H. W.; Van, D. P. J. Microbes in Action: A Laboratory Manual of Microbiology; D. B. Taraporevala Sons \& Co. Pvt. Ltd.: Bomay, 1975; p 55.

40. Barry, A. I. The Antimicrobial Suspectibility Test, Principles of Practices, 4th ed.; ELBS: 1976; p 80.

41. Horsfall, J. G. Bot. Rev. 1945, 11, 357.

42. Mc Beth, C. W.; Bergeson, G. B. Phytopathology 1953, 43, 264. 